\author{
CONSIDERAȚII ASUPRA PROIECTULUI \\ PENTRU MODIFICAREA ȘI COMPLETAREA \\ LEGII NR. $287 / 2009$ PRIVIND CODUL CIVIL, \\ A LEGII NR.134/2010 PRIVIND CODUL DE \\ PROCEDURĂ CIVILĂ, PRECUM SI A ALTOR \\ ACTE NORMATIVE ÎN MATERIA PROTECT,IEI \\ PERSOANELOR CU DIZABILITĂȚI
}

DOI: $\quad 10.24193 /$ SUBBiur.66(2021).2.2

\title{
Șerban DIACONESCU*
}

Rezumat: Implementarea în legislația națională a principiilor stabilite prin convenția de la New York din 2007, privind drepturile persoanelor cu dizabilități, deziderat la care face trimitere în considerente decizia Curții Constituționale nr. 601 din 16 iulie 2020, impune o schimbare de paradigmă a reglementării: limitarea capacității de exercițiu sau pierderea capacității de exercițiu va trebui să respecte principiile necesității, proporționalității și subsidiarității. Legiuitorul va trebui să ofere, prin noua reglementare, un sistem de protecție cu geometrie variabilă, care să permită instanței de tutelă să moduleze limitarea capacității în funcție de circumstanțele concrete în care se găsește persoana vulnerabilă atât din perspectiva facultăților mintale cât și din perspectiva situației patrimoniale. Noua reglementare

\footnotetext{
* Conf. univ. dr. Șerban Diaconescu, Facultatea de Drept a Universităţii Babeș-Bolyai din Cluj, avocat în Baroul Cluj, serban.diaconescu@law.ubbcluj.ro, https://orcid.org/0000-0003-16715003.Prezentul articol a fost publicat și în: In honorem Flaviu Antoniu Baias. Aparența în drept, Hamangiu, București, 2021, p. 752-773, și este republicat în paginile revistei cu acordul autorului. Articolul are în vedere legislația în vigoare la 31.08.2021.
} 
va trebui să găsească un echilibru între predictibilitatea limitelor capacității de exercițiu, reclamată de securitatea circuitului civil, și proporționalitatea măsurilor de protecție, care să se moduleze pe situația concretă a persoanei supusă măsurii și care să fie adecvată pentru situația patrimoniului său.

Cuvinte cheie: drepturile persoanelor cu dizabilităţi, capacitate civilă, proporționalitatea măsurilor de protecție.

\author{
CONSIDERATIONS ON THE DRAFT \\ REGARDING THE AMENDMENT AND \\ ADDITION OF LAW NO. 287/2009 ON THE \\ ROMANIAN CIVIL CODE, OF LAW NO. \\ $134 / 2010$ ON THE ROMANIAN CODE OF \\ CIVIL PROCEDURE, AS WELL AS OTHER \\ REGULATIONS ON THE PROTECTION OF \\ PERSONS WITH DISABILITIES
}

\begin{abstract}
The implementation in the national legislation of the principles established by the New York Convention of 2007, regarding the rights of persons with disabilities, desideratum to which the decision of the Constitutional Court no. 601 of 16 July 2020 is referring, requiring a paradigm shift in regulation: limitation of capacity or loss of capacity will have to comply with the principles of necessity, proportionality, and subsidiarity. The legislator will have to offer, through the new regulation, a protection system with variable geometry, which will allow the guardianship court to modulate the capacity limitation according to the material circumstances under which the vulnerable person finds him/her/self both from the perspective of mental faculties and from the patrimonial status. The new regulation will have to find a balance between the predictability of the limits of the capacity of exercise, demanded by the security of the civil circuit, and the proportionality of the protection measures, which should be modulated on the respective status of the person subject to the measure.
\end{abstract}

Keywords: the rights of persons with disabilities, civil capacity, the proportionality of the protection measures. 


\section{Cuprins}

I. Premise 55

A. $\quad$ Lipsa unor măsuri proporționale ............................................................. 57

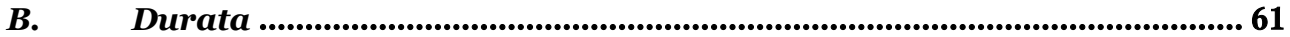

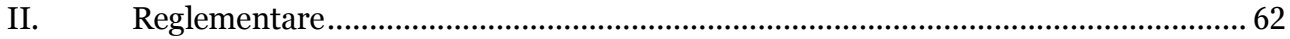

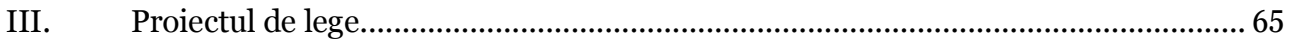

IV. Mandatul de ocrotire (mandat de protecție viitoare) ............................................ 67

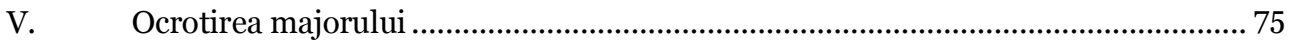

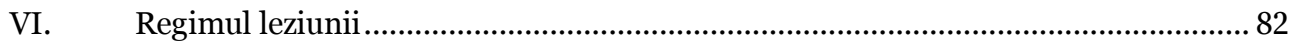

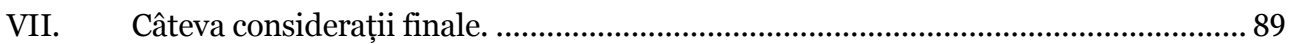

\section{Premise}

Prin decizia Curții Constituționale nr. 601 din 16 iulie $2020^{1}$ au fost declarate neconstituționale dispozițiile art. 164 C.civ. privitoare la punerea sub interdicție, în esență pentru faptul că nu prevăd măsuri graduale de protecție pentru persoana fizică afectată de tulburări mintale².

Curtea a reținut, în considerentele deciziei (pct. 46), că procedura de punere sub interdicție încălcarea prevederilor constituționale, art. 1 alin. (3), art. 16 și art. 50, astfel cum se interpretează potrivit art. 20 din Constituție și prin prisma art. 12 din Convenția privind drepturile persoanelor cu dizabilități, deoarece măsura de ocrotire a punerii sub interdicție

\footnotetext{
${ }^{1}$ Publicată în Monitorul Oficial numărul 88 din 27 ianuarie 2021.

2 Am analizat această decizie în articolul publicat în volumul dedicat d-nei profesor Emeşe Florian, Reflecții asupra incapacității persoanei majore în contextul Deciziei Curții Constituționale nr. 601 din 16 iulie 2020. Unele analize și argumente au fost preluate și în acest articol.
} 
judecătorească prevăzută de art. 164 alin. (1) din Codul civil nu este însoțită de suficiente garanții care să asigure respectarea drepturilor şi libertăţilor fundamentale ale omului. Aceasta nu ține cont de faptul că pot exista diferite grade de incapacitate şi nici de diversitatea intereselor unei persoane, nu se dispune pentru o perioadă determinată de timp și nu este supusă unei revizuiri periodice.

Prin urmare, curtea a reținut că orice măsură de ocrotire trebuie să fie proporţională gradului de capacitate, să fie adaptată la viața persoanei, să se aplice pentru cea mai scurtă perioadă de timp, să fie revizuită periodic și să țină cont de voința și preferințele persoanelor cu dizabilităţi. De asemenea, la reglementarea unei măsuri de ocrotire, legiuitorul trebuie să țină cont de faptul că pot exista diferite grade de incapacitate, iar deficiența mintală poate varia în timp. Lipsa capacității psihice sau a discernământului poate lua diferite forme, spre exemplu totală/parțială sau reversibilă/ireversibilă, situație care reclamă instituirea unor măsuri de ocrotire adecvate realității și care, însă, nu se regăsesc în reglementarea măsurii interdicţiei judecătorești. Diferitelor grade de dizabilitate trebuie să le fie ataşate grade de ocrotire corespunzătoare, legiuitorul în reglementarea măsurilor juridice trebuind să identifice soluții proporționale. O incapacitate nu trebuie să conducă la pierderea exercițiului tuturor drepturilor civile, ci trebuie analizată în fiecare caz în parte. Orice persoană trebuie să fie liberă să acționeze în vederea dezvoltării personalității sale, statul, în virtutea caracterului său social, având obligația de a reglementa un cadru normativ care să asigure respectarea individului, deplina exprimare a personalității cetățenilor, a drepturilor și libertăților lor, a șanselor egale, având ca rezultat respectarea demnității umane. 
Vulnerabilitatea persoanei generată de slăbiciunea sa mintală prezintă importanță în special în raporturile cu ceilalți, în circuitul civil. Punerea sub interdicție judecătorească (așa cum se reține și la punctul 29 din decizia Curții Constituționale a României) reprezintă o măsură de ocrotire a drepturilor și a intereselor legitime, patrimoniale și nepatrimoniale, ale persoanei fizice, instituită de instanța judecătorească în urma evaluării posibilităţii persoanei de a-şi exercita drepturile și de a-şi îndeplini obligațiile, iar aceasta trebuie stabilită în interesul persoanei, avându-se în vedere posibilitatea acesteia de a-și îndeplini obligațiile cu privire la sine și la bunurile sale (art.104 și 106 alin. (2) C.civ.). Următoarele deficiențe de fond au fost sesizate în legătură cu actuala reglementare:

\section{A. Lipsa unor măsuri proporționale}

Un prim reproș de fond la adresa actualei reglementări (pct. 30) vizează faptul că actuala reglementare a punerii sub interdicție instituie un regim substitutiv, astfel că drepturile și obligațiile unei persoane puse sub interdicție judecătorească vor fi exercitate de un reprezentant legal, indiferent de gradul de afectare a discernământului persoanei în cauză, în dauna unui regim de suport caracterizat printr-un mecanism de sprijin pe care statul să îl acorde în funcție de gradul de afectare a discernământului. Prin raportare la art. 50 din Constituție, care consacră dreptul persoanelor cu dizabilităţi de a se bucura de o protecție specială, precum și la Convenția (de la New York din 2007) privind drepturile persoanelor cu dizabilități, Curtea Constituțională a apreciat că orice măsură de protecție trebuie să fie proporțională cu gradul de capacitate, să fie adaptată la viața persoanei, să fie dispusă numai dacă alte 
măsuri nu pot oferi o protecție suficientă, să țină cont de voința persoanei, să se aplice pentru cea mai scurtă perioadă de timp și să fie revizuită periodic.

În considerente se mai reține că art. 12 pct. 2 din convenție, astfel cum a fost interpretat de Comitetul pentru drepturile persoanelor cu dizabilități prin Comentariul general nr.1/2014, precizează că toate persoanele cu dizabilități au dreptul la capacitate juridică completă. Capacitatea juridică este indispensabilă pentru exercitarea drepturilor civile, politice, economice, sociale şi culturale. Aceasta dobândește o semnificație specială pentru persoanele cu dizabilități atunci când trebuie să ia decizii fundamentale privind sănătatea, educația și munca lor. De asemenea, art. 12 pct. 2 din convenție recunoaște faptul că persoanele cu dizabilități se bucură de capacitate juridică în condiții de egalitate cu celelalte persoane, în toate domeniile vieții, iar capacitatea juridică și capacitatea mintală sunt concepte distincte. În lumina art. 12 pct. 3 al convenției, statul are obligația să ia toate măsurile adecvate pentru a asigura accesul persoanelor cu dizabilităţi la sprijinul de care ar putea avea nevoie în exercitarea capacităţii juridice. Potrivit art. 12 pct. 4 al convenției, este posibilă aplicarea unor măsuri de protecție asupra persoanelor cu dizabilități, adaptate la situația particulară a persoanei. Acestea vor fi proporționale cu gradul în care afectează drepturile şi interesele persoanei și vor fi adaptate la situația acesteia și vor respecta drepturile, voința și preferințele persoanei. Sub aspectul duratei pentru care se instituie o măsură de ocrotire și al revizuirii periodice a acesteia, art. 12 pct. 4 din Convenția privind drepturile persoanelor cu dizabilități reglementează faptul că o măsură de ocrotire se aplică pentru cea mai scurtă perioadă posibilă și se supune revizuirii periodice de către o autoritate competentă. 
Așadar, convenția consacră anumite garanții care trebuie să însoțească măsurile de protecție instituite în privința persoanelor cu dizabilităţi.

Și Recomandarea R(99)4 a Comitetului de Miniștri al Consiliului Europei privind principiile referitoare la protecția juridică a adulților aflați în incapacitate, adoptată la 23 februarie 1999, în principiile 3 și 6, stabilește că legislația națională ar trebui, pe cât posibil, să recunoască faptul că pot exista diferite grade de incapacitate și că incapacitatea poate varia în timp, iar ,în cazul în care este necesară o măsură de protecție, ea trebuie să fie proporțională cu gradul de capacitate al persoanei vizate și adaptată la circumstanțele și nevoile individuale ale persoanei vizate”. Totodată, Principiul 14 pct. 1 din Recomandarea R(99)4 a Comitetului de Miniștri al Consiliului Europei prevede durata limitată a măsurii de ocrotire și instituirea reexaminării periodice a acesteia (pct. 33).

Curtea reține (pct. 35) că, în concepția Convenției privind drepturile persoanelor cu dizabilități capacitatea juridică a persoanei nu se confundă cu capacitatea mintală a acesteia, fiind concepte distincte, iar limitările percepute sau reale în capacitatea mintală nu trebuie utilizate ca justificare a respingerii capacității juridice. Însă Codul civil operează cu valori absolute în sensul că orice potențială afectare a capacității mintale, indiferent de gradul său, poate duce la lipsirea persoanelor de capacitate de exercițiu, fără a exista posibilitatea ca o atare situație să fie evitată prin măsuri de suport necesare. Rezultă că există o distonanță paradigmatică între Convenția privind drepturile persoanelor cu dizabilități și Codul civil referitor la măsurile de ocrotire ce trebuie luate în privința persoanelor cu dizabilități, prima plasându-se în sfera măsurilor de suport și operând cu valori intermediare, pe când cel de-al doilea plasându-se într-un regim de substituție și a valorilor 
absolute, refuzând soluții intermediare adaptate situației particulare a fiecărei persoane.

Din această perspectivă, curtea observă (pct. 38) că, din modul de reglementare a măsurii punerii sub interdicție judecătorească, prin art. 164 alin. (1) din Codul civil, nu rezultă că aceasta vizează lipsa totală a discernământului persoanei raportat la multitudinea intereselor pe care le poate manifesta în diferitele domenii ale vieții. Deși Convenția privind drepturile persoanelor cu dizabilități stabilește că o măsură de ocrotire se instituie ținând cont de existența unor grade diferite de capacitate, legislația română prevede capacitatea de exerciţiu restrânsă numai în privința minorului cu vârsta cuprinsă între 14 și 18 ani (art. 38 şi art. 41 din Codul civil), nu și capacitatea de exerciţiu restrânsă a majorului care, ca urmare a punerii sub interdicție judecătorească, va fi lipsit în totalitate de aceasta, actele juridice urmând să se încheie, în numele acestuia, de un reprezentant legal. În consecință, Curtea reține (pct. 39) că efectele pe care le produce restricționarea capacității de exercițiu a unei persoane mai mult decât este necesar o poate poziționa, sub aspectul libertății de acțiune în domeniile în care manifestă o voință conștientă, într-o situație de inegalitate față de celelalte persoane care nu se află sub o măsură de ocrotire, fiind libere să-și exercite drepturile și să-și valorifice libertățile, cu consecințe asupra principiului egalității.

De aceea, având în vedere că există diferite grade de dizabilitate, iar o persoană poate să aibă într-o mai mare sau mai mică măsură discernământul afectat, dar nu în totalitate abolit, până la dispunerea unei măsuri care să restrângă capacitatea de exercițiu a persoanei trebuie luată în considerare instituirea unor măsuri alternative şi mai puțin restrictive decât punerea sub 
interdicţie judecătorească. În consecință, în lipsa acestor măsuri alternative îi revine legiuitorului sarcina să identifice şi să reglementeze mecanisme apte să ofere sprijinul necesar în luarea deciziilor bazate pe voința și preferința acestor persoane. Statul român trebuie să acorde sprijinul în exercitarea capacității juridice, prin dezvoltarea unor mecanisme bazate pe premisa respectării drepturilor, voinței și preferințelor persoanelor cu dizabilităţi, și, numai în măsura în care sprijinul astfel oferit se dovedește a fi ineficient, să reglementeze măsuri de ocrotire adaptate la situaţia particulară a persoanelor. Prin urmare, o măsură de ocrotire precum punerea sub interdicție judecătorească trebuie să fie reglementată doar ca o ultima ratio întrucât prezintă o gravitate extremă care implică pierderea drepturilor civile în ansamblul său și care trebuie analizată cu atenție de fiecare dată, inclusiv sub aspectul dacă alte măsuri s-au dovedit ineficiente în sprijinirea capacităţii civile a persoanei.

\section{B. Durata}

În opinia Curții (pct. 40) nici sub aspectul duratei pentru care se instituie măsura de ocrotire și nici sub aspectul revizuirii periodice a acesteia, actualul sistem de punere sub interdicție nu corespunde standardelor internaționale, potrivit cărora o măsură de ocrotire se aplică pentru cea mai scurtă perioadă posibilă și se supune revizuirii periodice de către o autoritate competentă. Pe de o parte, punerea sub interdicție și, implicit, tutela durează până la încetarea cauzelor care le-au provocat-o (art.177 alin. (1) C.civ.), motiv pentru care această garanție este una iluzorie, legiuitorul ar trebui să reglementeze dispunerea acesteia pe anumite intervale de timp pentru a da posibilitatea evaluării încetării cauzelor care au condus la instituirea măsurii. 
Aceste termene trebuie să fie fixe, prestabilite, ușor cuantificabile, suple și fără a avea o durată excesivă, care să permită revizuirea periodică a măsurii întrun mod eficient și coerent. În concluzie, având în vedere că există posibilitatea ca deficiența mintală să varieze în timp, punerea sub interdicție judecătorească pentru o perioadă nedeterminată și fără o reevaluare periodică a capacităţii persoanei aduce atingere drepturilor și intereselor persoanelor care, în anumite perioade, își pot conștientiza și coordona acțiunile. Așadar, măsura de ocrotire a persoanei cu deficiențe mintale trebuie fie individualizată raportat la gradul de incapacitate.

\section{Reglementare}

România a adoptat Convenția ONU, din 2007, cu privire la drepturile persoanelor cu dizabilități ${ }^{3}$, categorie care include acele persoane care au deficiențe fizice, mintale, intelectuale sau senzoriale de durată, deficiențe care, în interacțiune cu diverse bariere, pot îngrădi participarea deplină și efectivă a persoanelor în societate, în condiții de egalitate cu ceilalți (art. 1 alin. (2) al convenției). În anul 2006 au fost implementate şi mecanismele interne de monitorizare reclamate de convenție ${ }^{4}$.

Din perspectiva subiectului tratat, al protecţiei prin intermediul limitării sau pierderii capacităţii depline de exerciţiu este incident art. 12 al

\footnotetext{
3 Prin Legea nr. 221/2010, publicată în Monitorul Oficial cu numărul 792 din data de 26 noiembrie 2010.

${ }^{4}$ Prin Legea nr. 8/2016, publicată în Monitorul Oficial cu numărul 48 din data de 21 ianuarie 2016, privind înființarea mecanismelor prevăzute de Convenția privind drepturile persoanelor cu dizabilități.
} 
Convenției, recunoaștere egală în fața legii, care cuprinde următoarele principii:

„1. Statele părți reafirmă că persoanele cu dizabilități au dreptul la recunoașterea, oriunde s-ar afla, a capacității lor juridice.

2. Statele părți vor recunoaște faptul că persoanele cu dizabilități se bucură de asistență juridică în condiții de egalitate cu ceilalți, în toate domeniile vieții.

3. Statele părți vor lua toate măsurile adecvate pentru a asigura accesul persoanelor cu dizabilități la sprijinul de care ar putea avea nevoie în exercitarea capacității lor juridice.

4. Statele părți se vor asigura că toate măsurile legate de exercitarea capacității juridice prevăd protecția adecvată și eficientă pentru prevenirea abuzurilor, conform legislației internaționale privind drepturile omului. $\mathrm{O}$ astfel de protecție va garanta că măsurile referitoare la exercitarea capacității juridice respectă drepturile, voința și preferințele persoanei, nu prezintă conflict de interese și nu au o influență necorespunzătoare, sunt proporționale și adaptate la situația persoanei, se aplică pentru cea mai scurtă perioadă posibilă și se supun revizuirii periodice de către o autoritate competentă, independentă și imparțială sau de către un organ juridic. Măsurile de protecție vor fi proporționale cu gradul în care asemenea măsuri afectează drepturile și interesele persoanei.

5. În conformitate cu prevederile prezentului articol, statele părți vor lua toate măsurile adecvate și eficiente pentru a asigura dreptul egal al persoanelor cu dizabilități de a deține sau moșteni proprietăți, de a-și gestiona propriile venituri și de a avea acces egal la împrumuturi bancare, ipoteci și alte forme de credit financiar și se vor asigura că persoanele cu dizabilități nu sunt deposedate în mod arbitrar de bunurile lor."

De asemenea, art. 22 al convenției, cu privire la dreptul la viață personală, prevede:

\section{3}


„1. Nicio persoană cu dizabilități, indiferent de locul sau de tipul de reședință, nu va fi supusă intruziunii arbitrare sau nelegale în viața personală, în familia, căminul ori corespondența sa sau în alte tipuri de comunicare ori atacurilor ilegale la onoarea și reputația sa. Persoanele cu dizabilități au dreptul la protecția legii împotriva unor asemenea intruziuni sau atacuri.

2. Statele părți vor proteja confidențialitatea informațiilor referitoare la datele personale, medicale și de reabilitare ale persoanelor cu dizabilități, în condiții de egalitate cu ceilalți.”

Deși dezideratele existenței în legislația internă a unor măsuri de protecție limitate în timp și supuse unor revizuiri periodice, care să permită, în raport cu circumstanțele personale ale persoanei cu dizabilități mintale, aplicarea unor măsuri proporționale, erau cunoscute la data adoptării Codului civil, legiuitorul român a păstrat în mare măsură sistemul de protecție anterior, lipsit de nuanțe: lipsa totală a capacității de exercițiu, incapacitatea reglementată de art. 164 C.civ., sau curatela persoanei majore, caz în care persoana vulnerabilă poate încheia în continuare acte vătămătoare pentru sine, având în continuare capacitate deplină de exercițiu, curatorul neavând atribuții de asistare a celui în favoarea căruia lucrează.

Efectele acestor instrumente supranaționale de reglementare a situației persoanelor cu dizabilități reclamă o schimbare de paradigmă legislativă, care să implice, pe cât posibil, pe cei vulnerabili în adoptarea deciziilor care îi privesc, atât în ceea ce privește viața personală cât și în ceea ce privește administrarea patrimoniului.

\section{4}




\section{Proiectul de lege}

Proiectul de lege aflat în dezbatere publică ${ }^{5}$ face primii pași în direcţia acestei schimbări necesare de paradigmă și o atenție deosebită va trebui acordată modului în care aceste texte vor fi aplicate în practica judiciară, pentru ca sistemul național de protecție a persoanelor cu dizabilități să reușească să reprezinte cu adevărat un cadru eficient de atingere a obiectivelor reclamate de convențiile internaţionale, respectiv de decizia Curţii Constituționale a României, menționate în punctele anterioare. Din această perspectivă, considerăm important să analizăm instituțiile nou introduse sau, după caz, modificările propuse utilizând și repere de drept comparat, experiența sistemelor juridice care au implementat deja măsuri similare fiind, în opinia noastră, utilă.

Conform expunerii de motive, proiectul își propune realizarea unei intervenții substanțiale în materia măsurilor de ocrotire de drept civil de care pot beneficia persoanele fizice vulnerabile, cu reașezarea regulilor care configurează ocrotirea persoanei fizice cu dizabilități intelectuale și psihosociale pe fundamente noi, moderne, cu valorificarea reglementărilor internaționale în domeniu. Configurarea mecanismelor de drept civil de ocrotire a persoanei fizice majore vulnerabile este regândită pentru a așeza această persoană în centrul reglementării și a concilia nevoia sa (temporară ori permanentă) de a fi protejată cu imperativul respectării exercițiului drepturilor și libertăților sale fundamentale, marcând desprinderea definitivă

5 Proiectul a fost pus în dezbatere publică la 29.07.2021, pe site-ul Ministerului Justiției, https://www.just.ro/proiectul-de-lege-pentru-modificarea-si-completarea-legii-nr-2872009-privind-codul-civil-a-legii-nr-134-2010-privind-codul-de-procedura-civila-precum-sia-altor-acte-normative/, arhivă: https://perma.cc/2ZAU-ZHGA.

\section{5}


de regimul (unic și inflexibil) actual de ocrotire repudiat de instanța noastră de contencios constituțional.

Prin soluțiile legislative cuprinse în proiect se propune, în esență, reconfigurarea (și redenumirea) actualei instituții a punerii sub interdicție judecătorească, precum și crearea unui nou mecanism de ocrotire consilierea judiciară, întregul eşafodaj legislativ sprijinindu-se pe trei piloni fundamentali: necesitate (regimul de ocrotire este instituit cu scopul protejării, în mod adecvat, a persoanei vulnerabile) subsidiaritate (măsurile de ocrotire a majorului sunt dispuse numai în cazul în care instanța apreciază că nu este suficientă pentru apărarea intereselor persoanei ocrotite instituirea unei alte măsuri prevăzute de lege, aplicarea regulilor de drept comun instituite pentru ocrotirea unui interes general sau particular, a celor în materia reprezentării sau asistării, a celor referitoare la drepturile și obligațiile soților sau încuviințarea unui mandat de ocrotire încheiat de persoana în cauză) şi proporționalitate (regimul de ocrotire este corespunzător gradului de incapacitate și individualizat în funcție de nevoile celui pus sub ocrotire și de circumstanțele în care aceasta se găsește).

Proiectul își propune, totodată, o serie de garanții esențiale, reglementate în beneficiul celui ocrotit, cum ar fi instituirea unui sistem gradual, în trepte, de dispunere a măsurilor de ocrotire, a unor perioade determinate de timp pentru care pot fi dispuse și prelungite acestea, configurarea unor reguli privind reevaluarea periodică a regimului de ocrotire ales sau posibilitatea adaptării (individualizării) permanente, de către instanța de tutelă, a măsurii de ocrotire în funcție de circumstanțele concrete în care se găsește cel ocrotit. 


\section{Mandatul de ocrotire (mandat de protectie viitoare)}

O primă problemă asupra căreia am ales să ne oprim este cea a mandatului denumit de ocrotire în proiectul de lege, instituție cunoscută la nivel mondial cu denumirea de mandat de protecție viitoare. Respectarea principiilor Convenției de la New York din anul 2007 cu privire la protejarea persoanelor cu dizabilități reclamă și recunoașterea posibilității amenajării unui regim de protecție extrajudiciară, sub control public. Forma juridică cel mai des întâlnită este cea a mandatului de protecție viitoare, iar în statul canadian Quebec, unde sistemul a fost recunoscut în 1989, în prezent 30\% dintre persoanele care sunt supuse unui regim de protecție beneficiază de această formă specială de mandat, care devine eficace la momentul în care alterarea gravă a facultăților mintale este constatată printr-o expertiză medicală $\breve{b}^{6}$ Mecanismul de protecție privat pare să aibă un succes mai mare acolo unde mandatul de protecție viitoare este validat de judecătorul de tutelă (sau instituția echivalentă) și este de preferat, în opinia noastră, să fie supus unui sistem de publicitate eficient și unui control periodic riguros, similar cu cel al tutelei și al curatelei.

Prin proiectul de lege menționat se propune crearea unei noi forme de mandat, denumit mandat de ocrotire, deşi pentru rațiuni de compatibilitate cu instituții similare din alte sisteme de drept ar fi de preferat terminologia consacrată la nivel internațional, mandat de protecție viitoare:

\footnotetext{
6 B. Lefebvre, Vulnérabilité et aptitude, Rapport Général, în La Vulnérabilité, Ed. Brulyant, Bruxelles, 2020, p. 33.
} 
„Mandatul poate avea ca obiect și încheierea actelor destinate să asigure, în cazul survenirii incapacității mandantului de a se îngriji de persoana sa ori de a-și administra bunurile, ocrotirea persoanei mandantului, administrarea, în tot sau în parte, a bunurilor sale și, în general, bunăstarea sa morală și materială.”

Acest tip de mandat are un regim special, mandatarul, deşi de regulă împuternicit cu caracter general să administreze, în tot sau în parte, bunurile mandatului care necesită ocrotire, prin excepție, dacă a fost împuternicit expres cu administrarea deplină a bunurilor, poate încheia acte de înstrăinare sau grevare, tranzacții ori compromisuri, se poate obliga prin cambii sau bilete la ordin și poate intenta acțiuni în justiție, precum şi pentru a încheia orice alte acte de dispoziție.

În mod firesc, prin excepție de la regula de drept comun, efectele mandatului se produc doar de la data la care survine deteriorarea facultăților mintale ale mandantului, constatată ca urmare a întocmirii unor rapoarte de evaluare medicală și psihologică, care ar trebui să poată fi solicitate nu numai de către mandatarul desemnat ci şi de persoana vulnerabilă sau medicul curant sau eventual alți membrii ai familiei.

Pentru a asigura utilizarea și funcționalitatea acestei forme de ocrotire extrajudiciară considerăm oportună opțiunea legiuitorului, atât pentru forma autentică necesară pentru întocmirea sa cât și încuviințarea acestuia de către instanța de tutelă, la cererea mandatarului desemnat în contract. Poate nu ar fi lipsit de utilitate practică a extinde posibilitatea sesizării instanței de tutelă şi de către cel vulnerabil (atunci când discernământul ar fi doar diminuat) cât și de către alți membrii ai familiei, mai ales că, prin propunerea legislativă, revocarea mandatului de ocrotire ar urma să utilizeze aceeași procedură, 
aparent inclusiv în ceea ce privește titularul cererii (în contradicție cu propunerea de modificare de la art. 2030 alin. (2) C.civ.).

Încuviințarea instanței de tutelă, alături de verificarea legalității cuprinsului mandatului de protecție viitoare (ocrotire), conferă şi un grad ridicat de încredere participanților la circuitul civil, în vederea încheierii actelor, în special a celor de dispoziție, prin intermediul mandatarului numit de către cel vulnerabil. Chiar dacă propunerea prevede că instanța de tutelă poate, cu ocazia încuviințării mandatului, pentru a evita prejudicierea gravă a mandantului, să ia orice măsură necesară pentru ocrotirea persoanei mandantului, reprezentarea acestuia în exercitarea drepturilor și libertăților sale civile sau administrarea bunurilor lui, alegerea acestor măsuri, atunci când nu completează mandatul de ocrotire7, ci modifică cele hotărâte de persoana ocrotită, trebuie să fie făcută cu respectarea principiilor necesității, subsidiarității și proporționalității. Astfel, doar în măsura în care măsura se impune ca necesară, proporțional cu obiectivul de ocrotire urmărit, poate fi înlăturată dispoziția persoanei vulnerabile pentru situația în care nu se mai poate îngriji de situația sa materială și personală, modelul belgian (prezentat mai jos) de interpretare fiind, în opinia noastră, cel mai potrivit.

O particularitate a acestei forme de mandat o reprezintă faptul că nu se referă exclusiv la încheierea unor acte juridice având ca obiect bunuri din patrimoniul celui ocrotit ci permite mandantului să amenajeze și condiţiile de viață după survenirea incapacității, să stabilească reguli cu privire la îngrijirea sa și să desemneze persoana căreia mandatarul trebuie să dea socoteala (cel

\footnotetext{
7 Proiectul prevede în această ipoteză că „Actul prin care mandantul a încredințat deja altei persoane administrarea bunurilor sale continuă să producă efecte, cu excepția cazului în care acesta este revocat de către instanța de tutelă, pentru motive întemeiate. (s.n.)”
} 
puțin o dată la trei ani). În cazul în care prin mandatul de ocrotire (protecție viitoare) nu a fost desemnată o astfel de persoană, ea va fi desemnată de instanța de tutelă.

Principiile care guvernează îndeplinirea obligațiilor de către mandatar urmăresc respectarea cerințelor art. 12 și 22 din Convenția privind protecția persoanelor cu dizabilități (detaliate mai sus), în sensul că orice decizie referitoare la executarea mandatului este luată în interesul mandantului și asigură respectarea demnității, a drepturilor și libertăților acestuia, a voinței, nevoilor şi preferințelor lui, precum și salvgardarea autonomiei sale. Atunci când întinderea mandatului de ocrotire este îndoielnică, mandatarul îl interpretează conform regulilor privitoare la tutela specială a majorului. Ca o măsură suplimentară de protecție, atunci când situația concretă a mandantului o reclamă, instanța de tutelă va putea dispune și o altă măsură de ocrotire, cu respectarea principiului necesității și al proporționalității.

În opinia noastră, o omisiune a proiectului de lege o reprezintă, pentru mandatul de ocrotire (de protecție viitoare), lipsa cerinței verificării periodice, la un interval de timp precis stabilit, a existenței, în continuare, a condițiilor care reclamă aplicarea măsurii de protecție extrajudiciare. Deși există formal oricând posibilitatea ca mandantul redevenit capabil să revoce mandatul, precum și posibilitatea ca mandatarul, instituția sanitară care îngrijește periodic sau, în opinia noastră, chiar și cei apropiați să sesizeze instanța de tutelă pentru a constata încetarea mandatului de ocrotire, apreciem că întrunirea cerințelor reclamate de decizia Curții Constituționale impun și pentru această formă de protecție amenajată de persoana vulnerabilă o reevaluare obligatorie, periodică, de maniera celei prevăzute pentru consilierea judiciară (3 ani) sau tutelă (5 ani), dat fiind că, prin ipoteză, 
mandatul de ocrotire (de protecție viitoare), poate opera și independent de aceste măsuri de ocrotire.

De asemenea, apreciem că ar trebui construit un sistem de publicitate special, propunerea legislativă făcând trimitere doar la comunicarea hotărârii de încuviințare a mandatului de ocrotire, similar cu comunicările făcute în cazul instituirii tutelei. În epoca în care multe contracte se încheie în spaţiul virtual, este de dorit ca limitele în care mandatul de ocrotire (de protecție viitoare) a fost încuviințat să fie facil disponibile și comprehensibile, în caz contrar, existând riscul ca să apară reticențe la încheierea contractelor cu cei protejați prin această formă de ocrotire.

Trebuie să observăm însă lipsa totală din proiectul legislativ a unor măsuri suport care ar putea fi oferite și de regimul juridic al căsătoriei, în completarea regimului gestiunii paralele, concurente ${ }^{8}$ asupra bunurilor comune. În reglementarea actuală, oricare dintre soți poate încheia singur, în virtutea puterilor conferite de lege fiecărui soț (nu în calitate de reprezentant al celuilalt soț), o serie de acte juridice cu privire la bunurile comune, precum actele de conservare, de administrare, de administrare a patrimoniului sau actele de dispoziție cu titlu oneros referitoare la bunurile mobile care nu sunt supuse unor formalități de publicitate. Și acțiunile în justiție corespunzătoare pot fi exercitate singur, în nume propriu doar de către un singur soț. Art. 315 C.civ. permite unuia dintre soți, în ipoteza în care celălalt soț se află în imposibilitate de a-și manifesta voința, să solicite instanței de tutelă să îl numească ca reprezentant al acestuia pentru exercitarea drepturilor pe care le are potrivit regimului matrimonial. Această imposibilitate nu trebuie să fie

${ }^{8}$ Pentru detalii E. Florian, Dreptul familiei, Ed. C.H. Beck, București, 2016, p. 217-222. 
absolutăg , iar limitele și durata mandatului sunt stabilite de instanța de tutelă în funcție de împrejurări. Soțul poate fi numit, prin mandatul judiciar, să încheie acte nu numai pentru bunurile comune, ci și pentru bunurile proprii ale soțului reprezentat ${ }^{10}$. Ar fi fost de preferat ca acest regim de protecție, care implică soțul, să fie aprofundat și dezvoltat, după modelul abilitării familiale din dreptul francez sau măcar o trimitere către posibilitatea pentru soțul celui care necesită ocrotire de a solicita instanței de tutelă să aplice pentru bunurile celui ocrotit a unui sistem similar fiduciei.

În încheiere, prezentăm câteva repere de drept comparat, pentru a deschide o perspectivă corectă din care să fie interpretată noua reglementare privitoare la mandatul de ocrotire (de protecție viitoare):

Reforma legislativă belgiană din anul 2013, ajustată în anul 2018, a instituit un sistem de protecție care urmărește să stimuleze mecanismele de protecție extrajudiciare și, doar atunci când este necesar și proporțional cu nevoile celui supus măsurii, să intervină mecanisme de protecție legale (art. 488/1 C.civ. belgian ${ }^{11}$ ). Sistemul juridic belgian a apreciat că aderarea la Convenția ONU, din 2007, cu privire la drepturile persoanelor cu dizabilități, impune regândirea paradigmei mijloacelor de protecție, prioritare fiind mijloacele extrajudiciare. O persoană fizică are dreptul, în perioada în care se află încă în deplinătatea facultăților mintale, să desemneze un mandatar care să încheie anumite acte pe seama sa, fiind aplicabile regulile mandatului de drept comun, și, prin același act, să stabilească, pentru momentul la care facultățile sale mintale vor fi alterate, că mandatarul va putea, în continuare,

\footnotetext{
${ }^{9}$ Ibidem, p. 144.

${ }^{10}$ Ibidem, p. 145

11 J. L. RENCHON, Vulnérabilité et aptitude en Belgique, în La Vulnérabilité, Ed. Brulyant, Bruxelles, 2020, p. 100-108.
} 
să încheie acea categorie de acte în numele și pe seama celui protejat, chiar dacă facultățile sale mintale sunt din ce în ce mai alterate (art. 489, 490 C.civ. belgian). Măsurile de protecție legale pot fi dispuse de judecătorul de pace doar dacă și numai în măsura în care măsurile de protecție extrajudiciare sau cele legale deja aplicabile nu sunt suficiente (art. 492 C.civ. belgian).

În cazul în care intervine alterarea facultăților mintale, judecătorul poate cenzura conținutul mandatului de protecție doar în măsura în care vatămă vădit interesele celui protejat, iar la solicitarea celui protejat și/sau a protectorului numit anterior, judecătorul de pace poate dispune asupra executării mandatului (art. 490/1 C.civ. belgian). Cel protejat rămâne de principiu capabil, măsura incapacității rămâne subsidiară, doar pentru situațiile în care se apreciază a fi necesar pentru protecția celui vulnerabil.

Și legiuitorul francez a optat pentru prioritizarea măsurilor particulare de protecție, în special mandatul de protecție viitoare, sau aplicarea, acolo unde este posibil, a regimului de reprezentare între soți. Deși practica notarială cunoștea diferite forme de mandat prin care o persoană capabilă numea un reprezentant convențional pentru administrarea bunurilor sale în ipoteza în care ar fi afectat discernământul, legiuitorul francez a reglementat, în anul 2007, mandatul de protecție viitoare ${ }^{12}$, permițând titularului patrimoniului să amenajeze administrarea bunurilor sale pentru ipoteza în care facultățile sale mintale vor fi afectate. Efectele mandatului se produc de la momentul la care declarația medicală de inaptitudine este vizată de grefă (art. 481 C.civ.fr.), însă titularul rămâne capabil, chiar dacă practic suntem în prezența unei capacități diminuate. Și în acest caz eventualele acte încheiate

12 Ph. Malaurie, L. Aynès, Droit civil. Les Personnes, Ed. Defrénois, Paris, 2010, p. 305, nr. 734. 
singur de către cel care beneficiază de un mandat de protecție intrat în vigoare pot fi desfiinţate sau adaptate pentru leziune (art. 488 C.civ.fr.). Regimul juridic al mandatului de protecție viitoare a fost reconfigurat prin ordonanța nr. 1288/2015 (art. $477^{13}$ și 477^1 C.civ.fr.) și a fost introdusă și o formă de publicitate pentru această măsură, publicarea într-un registru special.

Legiuitorul francez, chiar dacă a efectuat o reformă amplă a reglementării de protecție pentru persoanele vulnerabile, în anul 2006, a apreciat că se impune, pentru a respecta drepturile reglementate prin Convenția ONU din 2007 cu privire la drepturile persoanelor cu dizabilități, ajustarea reglementării pentru a răspunde unor standarde mai înalte de protecție $^{14}$. Ca repere de orientare poate fi reținut principiul necesității, cu corolarul său, subsidiaritatea, care implică recunoașterea unor mecanisme private de protecție (mandat de protecție viitoare, abilitare familială) care ar putea permite să fie evitată pierderea capacității de exercițiu, respectiv existența unui sistem de protecție (suport) judiciară care nu afectează

„Toute personne majeure ou mineure émancipée ne faisant pas l'objet d'une mesure de tutelle ou d'une habilitation familiale peut charger une ou plusieurs personnes, par un même mandat, de la représenter pour le cas où, pour l'une des causes prévues à l'article 425, elle ne pourrait plus pourvoir seule à ses intérêts.

La personne en curatelle ne peut conclure un mandat de protection future qu'avec l'assistance de son curateur.

Les parents ou le dernier vivant des père et mère, ne faisant pas l'objet d'une mesure de curatelle ou de tutelle ou d'une habilitation familiale, qui exercent l'autorité parentale sur leur enfant mineur ou assument la charge matérielle et affective de leur enfant majeur peuvent, pour le cas où cet enfant ne pourrait plus pourvoir seul à ses intérêts pour l'une des causes prévues à l'article 425, désigner un ou plusieurs mandataires chargés de le représenter. Cette désignation prend effet à compter du jour où le mandant décède ou ne peut plus prendre soin de l'intéressé.

Le mandat est conclu par acte notarié ou par acte sous seing privé. Toutefois, le mandat prévu au troisième alinéa ne peut être conclu que par acte notarié."

14 D. Noguéro, Vulnérabilité et aptitude en France, în La Vulnérabilité, Ed. Brulyant, Bruxelles, 2020, p. 197. 
automat capacitatea de exercițiu ci permite, însoțit de un sistem de publicitate adecvat, o reevaluare a actului, similară cu reglementarea leziunii la minori în dreptul intern, ulterioară încheierii sale din perspectiva utilității actului pentru cel ocrotit și a echivalenței prestațiilor.

Dreptul spaniol ${ }^{15}$ recunoaște și el o formă incipientă de mandat de protecție viitoare, o modificare a art. 1732 C.civ. spaniol, din anul 2003, a introdus o excepție de la principiul încetării mandatului în cazul survenirii incapacității mandantului, permițând celui reprezentat să prevadă că acesta va produce efecte și după survenirea incapacității, și a fost introdus conceptul de mandat de protecție, care începe să producă efectele numai la momentul survenirii incapacităţii mandantului. Reglementările locale catalane merg mai departe, și recunosc mandatul de protecție viitoare printre mijloacele reglementate de protecție pentru persoanele afectate de tulburări mintale, permițând mandantului, anterior tulburării, să stabilească unele reguli de administrare a bunurilor sale şi, eventual, un mecanism de verificare a activităţii mandatarului ${ }^{16}$.

\section{Ocrotirea majorului}

Prin proiectul de reformă se propune, pentru ocrotirea majorului, alături de clasica măsură a curatelei, o formă reconfigurată a interdicției judecătorești, denumită tutela specială (pentru a înlătura conotațiile denigratoare ale denumirii anterioare), și un regim juridic asimilat capacităţii

15 C. Guilarte Martin-CALERo, Vulnérabilité et aptitude en Espagne, în La Vulnérabilité, Ed. Brulyant, Bruxelles, 2020, p. 159-164.

16 Ibidem, p. 162, cu referire la art. 222-2 din Codul civil al Cataloniei. 
de exercițiu restrânse, denumit consiliere judiciară (art. 106 alin. (2) şi 164 din propunere). Deși sistemul are avantajul simplității și predictibilității, prin raportare la regimuri juridice cunoscute în circuitul civil, aplicarea mecanică a măsurilor de ocrotire doar pe două paliere riscă să facă reglementarea a fi considerată în continuare că nu respectă principiile necesității și cel al proporționalității:

„Art. 164. Condiţii

(1) Majorul care nu se poate îngriji singur de interesele sale din cauza unei deteriorări temporare sau permanente, parțiale sau totale, stabilită în urma unei evaluări medicale și psihosociale, a facultăților mintale, și care are nevoie de sprijin în formarea sau exprimarea voinței sale, poate beneficia de consiliere judiciară sau tutelă specială, dacă luarea acestei măsuri este necesară pentru exercitarea capacității sale civile, în condiții de egalitate cu celelalte persoane.

(2) O persoană poate beneficia de consiliere judiciară dacă deteriorarea facultăților sale mintale este parțială și este necesar să fie asistată sau consiliată în mod continuu în exercitarea drepturilor și libertăților ei.

(3) Instituirea consilierii judiciare se poate face numai dacă nu poate fi asigurată o protecție adecvată a persoanei ocrotite prin instituirea curatelei în condițiile art. 178-186.

(4) O persoană poate beneficia de tutelă specială dacă deteriorarea facultăților sale mintale este totală și este necesar să fie reprezentată în mod continuu în exercitarea drepturilor și libertăților ei.

(5) Instituirea tutelei speciale se poate face numai dacă nu poate fi asigurată o protecție adecvată a persoanei ocrotite prin instituirea curatelei sau prin punerea sa sub consiliere judiciară."

Pentru a evita o astfel de apreciere, prin art. 104 alin. (3) - 5 și, mai ales, 164 alin. (4), se transferă instanței de tutelă răspunderea pentru modelarea regimului juridic de ocrotire, astfel încât prin hotărârea de adoptare a măsurii de ocrotire, instanța va trebui să motiveze limitarea capacității de exercițiu doar la ceea ce este absolut necesar și 
proporționalitatea regimului juridic cu nevoile și situația concretă a persoanei care are nevoie de ocrotire:

„(3) Măsurile de ocrotire a majorului și deciziile cu privire la persoana sa asigură respectarea demnității, a drepturilor și libertăților acestuia, a voinței, nevoilor și preferințelor lui, precum și salvgardarea autonomiei sale. Incapacitatea rezultată este stabilită numai în favoarea sa.

(4) Măsurile de ocrotire a majorului sunt dispuse pentru cel mai scurt termen posibil, numai în caz de necesitate și sunt proporționale și individualizate în funcție de gradul de alterare a facultăților mintale, precum și de necesitățile persoanei ocrotite și circumstanțele în care aceasta se găsește.

(5) Măsurile de ocrotire a majorului sunt dispuse numai în cazul în care instanța apreciază că nu este suficientă pentru apărarea intereselor persoanei ocrotite instituirea unei alte măsuri prevăzute de lege, aplicarea regulilor de drept comun instituite pentru ocrotirea unui interes general sau particular, a celor în materia reprezentării sau asistării, a celor referitoare la drepturile și obligațiile soților sau încuviințarea unui mandat de ocrotire încheiat de persoana în cauză.

\section{$\stackrel{*}{* *}$}

Art. 168 (4) „Prin hotărârea prin care a fost dispusă punerea sub consiliere judiciară sau tutelă specială instanța de tutelă poate stabili, în funcție de gradul de autonomie al persoanei ocrotite și de nevoile sale specifice, categoriile de acte pentru care este necesară încuviințarea actelor sale sau, după caz, reprezentarea ei. Instanța poate dispune ca măsura de ocrotire să privească chiar și numai o categorie de acte. De asemenea, instanța poate dispune ca măsura de ocrotire să se refere numai la persoana celui ocrotit sau numai la bunurile sale."

Acest ultim text permite, în opinia noastră, ca instanța să dispună în cazul unor persoane care sunt afectate doar de o alterare parțială a facultăților mintale, eventual în legătură cu anumite activităţi, să fie reprezentate doar la încheierea unor categorii de acte, eventual legate de acele activităţi, pentru 
orice alte categorii de acte având regimul juridic al unei persoane cu capacitate de exercițiu deplină. După modelul propus de dreptul german ${ }^{17}$, pentru a adapta măsura de protecție la situația concretă a persoanei vulnerabile o inedită incapacitate parțială ar putea fi dispusă, interdicția vizând exclusiv anumite categorii de acte exclusiv dintr-un anumit domeniu, cum ar fi, spre exemplu, ipoteza în care unei persoane devenite procesomană, datorită unei obsesii psihologice, îi este restricționat dreptul de a mai formula singură acțiuni în justiție.

Va constitui o serioasă provocare formarea unei practici judiciare la instanțele de tutelă care, în analiza măsurilor concrete, să facă legătură între situația concretă a persoanei ocrotite și dezideratele reglementărilor moderne privind protecția persoanelor cu dizabilități. Evoluția mecanismelor prin care se asigură protecția persoanelor cu tulburări mintale în dreptul francez prezintă un bun model, pe de o parte pentru că reglementarea inițială în dreptul român privind punerea sub interdicție a fost inspirată de vechea reglementare franceză, iar pe de altă parte pentru că decizia Curţii Constituționale a României face trimitere la legislația actuală franceză ca model (pct. 41).

În dreptul francez ${ }^{18}$, regimul de protecție al persoanelor majore vulnerabile datorită situației lor psihologice sau medicale este guvernat de principiile necesității, subsidiarităţii și proporţionalității ${ }^{19}$ : aplicarea măsurilor de protecție nu poate interveni decât în ipoteza în care: a) alterarea

17 G. REInER, Vulnérabilité et aptitude en Allemagne, în La Vulnérabilité, Ed. Brulyant, Bruxelles, 2020, p. 77-79.

18 Art. 425 și urm. Cod civil francez, modificate prin legea nr. 308 din 5 martie 2007, intrată în vigoare la 1 ianuarie 2009.

19 Ph. Malaurie, L. AynÈs, op.cit., p. 290-291, nr. 704. 
facultăților mintale, stabilită printr-o expertiză medicală, o justifică; b) nu există alte instituții, mai puțin constrângătoare, care să permită protejarea persoanei afectate (cum ar fi incidența instituției abilitării familiale sau existența unui mandat civil anterior care să permită administrarea patrimoniului persoanei vulnerabile); c) măsura de protecție să fie individualizată în funcție de circumstanțele concrete legate de alterarea facultăților mintale, în care se află persoana protejată. Aplicarea acestor principii a fost rafinată cu ocazia modificării art. 428 C.civ.fr. în anul 2019²0, iar propunerea de lege pare să se fi orientat prioritar către această reglementare.

Din păcate, legiuitorul român, prin proiectul de lege, nu a propus și măsura de protecție prevăzută la art. 435 C.civ.fr., după modificarea adusă Codului civil în anul 2016, sub denumirea „sauvegarde de justice”. Această formă de protecție, diferită de curatelă, a fost adaptată noilor imperative, în esență protecția acordată pe această cale nu presupune pierderea capacităţii de exercițiu ${ }^{21}$ ci doar plasarea sub protecție a persoanei care fie este afectată

${ }^{20}$ După modificarea adusă de art. 29 al Legii nr. 222 din 23 martie 2019, art. 428 are următorul conținut:

„La mesure de protection judiciaire ne peut être ordonnée par le juge qu'en cas de nécessité et lorsqu'il ne peut être suffisamment pourvu aux intérêts de la personne par la mise en ouvre du mandat de protection future conclu par l'intéressé, par l'application des règles du droit commun de la représentation, de celles relatives aux droits et devoirs respectifs des époux et des règles des régimes matrimoniaux, en particulier celles prévues aux articles 217 , 219, 1426 et 1429 ou, par une autre mesure de protection moins contraignante.

La mesure est proportionnée et individualisée en fonction du degré d'altération des facultés personnelles de l'intéressé."

$21 \quad$ La personne placée sous sauvegarde de justice conserve l'exercice de ses droits. Toutefois, elle ne peut, à peine de nullité, faire un acte pour lequel un mandataire spécial a été désigné en application de l'article 437."

Les actes qu'elle a passés et les engagements qu'elle a contractés pendant la durée de la mesure peuvent être rescindés pour simple lésion ou réduits en cas d'excès alors même qu'ils 
de o imposibilitate temporară de a-și exprima voința și a proteja interesele sale datorită alterării facultăților mintale, fie face obiectul unei proceduri judiciare de instituire a curatelei sau a tutelei. În doctrina franceză ${ }^{22}$ se consideră că în această ipoteză discutăm despre o persoană cu capacitate diminuată. Este o măsură temporară, poate fi dispusă pe durata unui an și reînnoită o singură dată.

Pentru ipoteza în care este necesară încheierea anumitor acte, judecătorul poate institui un mandatar special care să încheie unul sau mai multe acte determinate necesare pentru gestionarea patrimoniului persoanei vulnerabile (art. 437 C.civ.). Deși cel plasat sub protecția justiției păstrează capacitatea civilă, măsura atrage un regim special pentru actele sale. Pe de o parte el nu poate încheia actele determinate (de principiu de dispoziție), pentru care i-a fost numit, de către instanța specializată, un mandatar. Pe de altă parte, actele încheiate de persoana vulnerabilă plasată sub protecția justiției beneficiază de o protecție suplimentară prin aplicarea unui regim special al leziunii, inclusiv din perspectiva utilității actului pentru cel protejat. De asemenea, rămâne aplicabilă anularea actului pentru lipsa discernământului.

Similar, în dreptul italian ${ }^{23}$, prin Legea nr. 6/2004, alături de mijloacele clasice de protecție pentru persoanele a căror discernământ este

pourraient être annulés en vertu de l'article 414-1. Les tribunaux prennent notamment en considération l'utilité ou l'inutilité de l'opération, l'importance ou la consistance du patrimoine de la personne protégée et la bonne ou mauvaise foi de ceux avec qui elle a contracté.

L'action en nullité, en rescision ou en réduction n'appartient qu'à la personne protégée et, après sa mort, à ses héritiers. Elle s'éteint par le délai de cinq ans prévu à l'article 2224." 22 Ph. Malaurie, L. AynÈs, op.cit., p. 299, nr. 723.

23 A. Venchiarutti, Vulnérabilité et aptitude en Italie, în La Vulnérabilité, Ed. Brulyant, Bruxelles, 2020, p. 215 -218. 
afectat de tulburări mintale, tutela și curatela, a fost introdusă o instituție nouă, amministrazione di sostegno, o formă de asistență de suport care urmărește să protejeze persoana vulnerabilă, de o manieră care să limiteze cât mai puțin posibil capacitatea de exercițiu a celui afectat. A fost concepută ca o măsură de protecție care să poată fi adaptată nevoilor particulare, concrete ale celui protejat, prin măsuri de susținere temporare sau permanente. Judecătorul de tutelă are sarcina de a defini, pentru fiecare persoană protejată, actele pe care persoana numită să acorde asistența le poate încheia în numele celui vulnerabil, respectiv actele pe care persoana care cade sub incidența acestei măsuri le poate încheia doar cu asistența celui numit să îl protejeze. Chiar dacă prin această măsură de protecție capacitatea de exercițiu este într-un fel limitată, de principiu persoana sprijinită în acest fel nu este considerată că a pierdut capacitatea de exercițiu sau că ar avea o capacitate de exercițiu restrânsă. Doar dacă persoana supusă măsurii are intelectul grav afectat, persoana numită să asigure suportul va primi dreptul de administrare a patrimoniului celui protejat.

În dreptul francez, dacă măsurile de abilitare familială sau „sauvegarde de justice” nu pot asigura o protecție suficientă persoanei vulnerabile, instanța va face apel la măsura curatelei (art. 440 C.civ.fr.), iar dacă nici aceasta nu răspunde nevoilor de protecție ale persoanei se poate dispune instituirea unei tutele (art. 441 C.civ.fr.). Prin legea nr. 177/2015 s-a stabilit că ambele măsuri pot fi dispuse pentru o durată de maxim 5 ani (prin excepție o tutelă poate fi stabilită pentru o durată de 10 ani) și reînnoite la expirarea termenului, pentru aceeași durată (în cazul tutelei prin excepție se poate prelungi măsura pentru o durată de 20 de ani) sau o durată mai scurtă dacă circumstanțele particulare ale persoanei protejate o impun. Legiuitorul 
român pare să se fi inspirat din această reglementare în ceea ce privește durata tutelei speciale, termenele propuse prin art. 168 din proiect fiind identice (mai puțin posibilitatea reînnoirii pentru 20 de ani), iar pentru consilierea judiciară termenul maxim este de 3 ani.

O altă modificare în dreptul francez, adusă prin legea nr. 222/2019 prevede dreptul persoanei vulnerabile de a decide cu privire la propria persoană, în măsura în care starea mintală îi permite acest lucru (art. 459 C.civ.fr.). În ipoteza în care starea mintală a persoanei protejate nu-i permite să ia o astfel de decizie persoana însărcinată cu protecția sa nu poate lua o decizie care să afecteze grav viața privată a celui ocrotit decât cu acordul instanței de tutelă. În acest sens apreciem că trebuie interpretate și dispozițiile art. 104 alin. (3) din proiectul de lege român.

În fine, în măsura în care practica judiciară se va cristaliza înspre stabilirea unor regimuri juridice de ocrotire cu geometrie variabilă (în ceea ce privește actele pe care le poate încheia cel sub ocrotire) apreciem că se impune, la fel ca în cazul mandatului de ocrotire (de protecție viitoare) înființarea unui sistem de publicitate suplimentar, care să permită verificarea limitelor capacității unui subiect de drept care nu se încadrează nici la categoria celor lipsiți de capacitate și nici la categoria celor cu capacitate de exercițiu restrânsă.

\section{Regimul leziunii}

Proiectul de lege propune şi unele inovații în regimul juridic al actelor încheiate de persoanele ocrotite. O propunere intrigantă conține proiectul de lege la art. 46 al. (3): 
„Persoana capabilă de a contracta nu poate opune anulabilitatea contractului și nici exercita acțiunea în anulare, însă poate cere menținerea contractului și reducerea sau majorarea propriei prestații, după caz.”

Acest text trebuie coroborat cu dispozițiile art. 172 C.civ. în forma propusă spre modificare:

„Art. 172. Actele încheiate de cel pus sub consiliere judiciară sau tutelă specială

Actele juridice încheiate de persoana pusă sub consiliere judiciară sau tutelă specială, altele decât cele prevăzute la art. 41 alin. (3) și la art. 43 alin. (3), precum și cele autorizate de instanța de tutelă, sunt anulabile sau obligațiile care decurg din acestea pot fi reduse, chiar fără dovedirea unui prejudiciu și chiar dacă la data încheierii lor aceasta ar fi avut discernământ.”

Coroborând cele două propuneri, putem trage concluzia că legiuitorul a apreciat că trebuie să ofere cocontractantului celui ocrotit, chiar și în ipoteza în care cunoştea despre instituirea măsurilor de ocrotire (consiliere judiciară sau tutelă specială) posibilitatea de a solicita menținerea contractului, în măsura în care ar oferi echilibrarea prestațiilor, fie prin reducerea, fie prin majorarea propriei prestații.

La prima vedere, textul reprezintă o aplicare a dreptului comun în materie de adaptare în cazul leziunii (art. 1222 coroborat cu art. 1213 C.civ.) însă, în realitate, există două neconcordanțe majore, care ar trebui clarificate, dacă nu înlăturate. În primul rând, până în prezent, regulile privind leziunea în cazul minorilor (art. 1221 alin. (3) C.civ. în forma actuală) erau derogatorii de la dreptul comun, regimul de protecție fiind aplicabil nu doar în cazul existenței unui dezechilibru între prestații ci și în cazul în care actul nu este în mod real util pentru minor, protecția acestuia fiind mai larg asigurată

\section{3}


deoarece instanța are un criteriu mult mai lax de apreciere decât în cazul majorilor (în formularea textului legal atunci când minorul își asumă o obligație excesivă prin raportare la starea sa patrimonială, la avantajele pe care le obține prin contract ori la ansamblul circumstanțelor ${ }^{24}$ ). Prin proiectul de lege se propune și modificarea corespunzătoare a textelor Codului civil în materia leziunii, prin eliminarea actualului art. 1221 alin. (3) C.civ., fără a lămuri dacă se păstrează regimul juridic cunoscut prin simpla referire la natura și scopul contractului (care nu este particulară pentru persoanele ocrotite). Considerăm opțiunea legiuitorului greșită, regimul juridic anterior oferind o mai bună protecție persoanelor vulnerabile, cu luarea în considerare a fundamentului diferit al leziunii în cazul persoanelor ocrotite.

Sursa de inspirație pare să fie dreptul francez, unde regimul sancționator al actelor încheiate cu nerespectarea condițiilor legale prevăzute pentru persoanele protejate prin curatelă sau tutelă a fost modificat în anul 2016. Pentru anumite categorii de acte juridice încheiate de cel protejat, art. 465 C.civ.fr. ${ }^{25}$, coroborat cu art. 1151 C.civ.fr., permit menținerea actului,

${ }^{24}$ P. VAsilescu, Drept civil. Obligații, Ed. Hamangiu, București, 2017, p. 373.

25 „A compter de la publicité du jugement d'ouverture, l'irrégularité des actes accomplis par la personne protégée ou par la personne chargée de la protection est sanctionnée dans les conditions suivantes:

$1^{\circ}$ Si la personne protégée a accompli seule un acte qu'elle pouvait faire sans l'assistance ou la représentation de la personne chargée de sa protection, l'acte reste sujet aux actions en rescision ou en réduction prévues à l'article 435 comme s'il avait été accompli par une personne placée sous sauvegarde de justice, à moins qu'il ait été expressément autorisé par le juge ou par le conseil de famille s'il a été constitué ;

$2^{\circ}$ Si la personne protégée a accompli seule un acte pour lequel elle aurait dû être assistée, l'acte ne peut être annulé que s'il est établi que la personne protégée a subi un préjudice ;

$3^{\circ}$ Si la personne protégée a accompli seule un acte pour lequel elle aurait dû être représentée, l'acte est nul de plein droit sans qu'il soit nécessaire de justifier d'un préjudice ;

\section{4}


chiar la cererea cocontractantului capabil, dacă se dovedește că actul încheiat este util pentru cel protejat și nu este lezionar. Numai că art. 465 C.civ.fr. face trimitere la art. $435^{26}$ cât privește regimul juridic al leziunii în cazul persoanelor ocrotite, care are o reglementare similară cu cea actuală din dreptul român în ceea ce privește aprecierea leziunii la minori. Doctrina franceză ${ }^{27}$ a apreciat regretabilă interferența dreptului comun al contractelor asupra sancțiunilor aplicabile actelor încheiate de majorul protejat, anticipând o scădere a protecției acordate persoanelor vulnerabile.

Aceeași critică trebuie adusă și actualei propuneri legislative. Reglementarea poate fi privită în cheia juridică a echilibrului între securitatea circuitului civil și protecția persoanelor vulnerabile, iar eficiența măsurii apreciem că este discutabilă în măsura în care o persoană pusă sub ocrotire nu va putea cere desființarea unui act inutil pentru ea, încheiat datorită forței

$4^{\circ}$ Si le tuteur ou le curateur a accompli seul un acte qui aurait dû être fait par la personne protégée soit seule, soit avec son assistance ou qui ne pouvait être accompli qu'avec l'autorisation du juge ou du conseil de famille s'il a été constitué, l'acte est nul de plein droit sans qu'il soit nécessaire de justifier d'un préjudice."

„Le curateur ou le tuteur peut, avec l'autorisation du juge ou du conseil de famille s'il a été constitué, engager seul l'action en nullité, en rescision ou en réduction des actes prévus $\operatorname{aux} 1^{\circ}, 2^{\circ}$ et $3^{\circ}$.

Dans tous les cas, l'action s'éteint par le délai de cinq ans prévu à l'article 2224.

Pendant ce délai et tant que la mesure de protection est ouverte, l'acte prévu au $4^{\circ}$ peut être confirmé avec l'autorisation du juge ou du conseil de famille s'il a été constitué."

26 „La personne placée sous sauvegarde de justice conserve l'exercice de ses droits. Toutefois, elle ne peut, à peine de nullité, faire un acte pour lequel un mandataire spécial a été désigné en application de l'article 437.

Les actes qu'elle a passés et les engagements qu'elle a contractés pendant la durée de la mesure peuvent être rescindés pour simple lésion ou réduits en cas d'excès alors même qu'ils pourraient être annulés en vertu de l'article 414-1. Les tribunaux prennent notamment en considération l'utilité ou l'inutilité de l'opération, l'importance ou la consistance du patrimoine de la personne protégée et la bonne ou mauvaise foi de ceux avec qui elle a contracté."

27 D. Noguéro, Vulnérabilité et aptitude en France, în La Vulnérabilité, Ed. Brulyant, Bruxelles, 2020, p. 197. 
de convingere a celeilalte părți asupra unei persoane cu discernământ afectat, pentru simplul fapt că nu ar exista un dezechilibru între prestații.

În al doilea rând, spre deosebire de ipoteza de drept comun, care și în forma actuală și în forma propusă spre modificare lasă o marjă de apreciere instanței (instanța poate să mențină contractul ... ) art. 46 alin. (3), în forma propusă, constituie o dispoziție specială, iar formularea textului (Persoana capabilă de a contracta ... poate cere menținerea contractului și reducerea sau majorarea propriei prestații, după caz) duce mai degrabă către interpretarea conform căreia cocontractantul are dreptul de a menține contractul, după regulile generale de la art. 1213 C.civ., riscând astfel să fie vătămate grav interesele persoanelor ocrotite.

În final, câteva observații suplimentare cu privire la propunerile de modificare a regimului juridic al leziunii prin proiectul de lege. Apreciem benefică explicitarea suplimentară a ipotezelor în care poate opera leziunea, prin includerea la ipotezele expres prevăzute de lege a raporturilor de dependență $\breve{2}^{28}$ și menționarea posibilităţii existenței unor alte ipoteze particulare: Există leziune atunci când, la data încheierii contractului, una dintre părți, profitând de starea de nevoie sau de dependență, de lipsa de experiență ori de lipsa de cunoștințe a celeilalte părți sau de alte circumstanțe particulare, obține în favoarea sa ori a unei alte persoane o prestație considerabil mai mare sau un beneficiu excesiv și nerezonabil în

\footnotetext{
28 Am definit contractele de dependență economică ca fiind acorduri care guvernează o activitate derulată sub formă profesionalizată, în care unul dintre parteneri, cel aservit, este tributar, pentru existența și supraviețuirea sa (economică s.n.), relațiilor permanente, privilegiate sau exclusive, stabilite cu cocontractantul său, partener privilegiat, cu efectul plasării în dependență economică față de acesta, sub dominația sa. Pentru dezvoltări în Ș. Diaconescu, Contractul-cadru de distribuție comercială, Ed. Universul Juridic, București, 2010, p. 69-80.
} 
raport cu valoarea propriei prestații.” Lăudabilă este și clarificarea unui alt aspect, de natură a lămuri caracterul particular și marginal al elementului subiectiv al leziunii: „Simplul fapt al existenței unei disproporții considerabile prezumă exploatarea.”. Și modificarea regimului prescripției apreciem că este benefică, termenul de un an curgând nu de la încheierea contractului, ca în reglementarea actuală, ci „de la data când obligația celui lezat a devenit exigibilă sau dacă exploatarea de care a profitat cealaltă parte a subzistat și după această dată, de la data când exploatarea a încetat."

În schimb, propunerea de înlăturare a actualului art. 1222 C.civ., care condiționează aplicarea sancțiunilor specifice leziunii în cazul majorului de existența unei disproporții între prestații de cel puțin jumătate din valoarea prestației considerăm că riscă să perturbe grav circuitul civil. Așa cum se arată în doctrină ${ }^{29}$, a accepta reducerea prestației celui dezavantajat indiferent de valoarea diferenței valorice dintre prestații ar echivala cu dinamitarea principiului stabilității contractelor, oricine și oricând va putea pretinde că există o disproporție între prestații antamând astfel procese interminabile, lăsând la o parte faptul că echilibrul între prestațiile părților nu a fost niciodată și nici nu poate fi vreodată unul farmaceutic, obiectiv, depinzând de condițiile concrete ale fiecărui contract în parte. A lăsa la aprecierea instanței ce înseamnă, de la caz la caz, o disproporție considerabilă, prin raportare și la

${ }^{29}$ Dan CHIRICĂ, Leziunea între vechiul și Noul Cod civil, în SUBB Iurisprudentia, nr. 4/2013, p. 25-44, disponibil la: http://arhiva-studia.law.ubbcluj.ro/articol/574, arhivă: https://perma.cc/9XYU-C7FH, iar pentru contractele de afaceri se arată în L. BERCEA, $O$ analiză a leziunii în contractele de afaceri, în R.R.D.P., nr. 1/2019, că „raporturile de afaceri, respectiv în contractele dintre profesioniști, (sunt) predispuse la asimetrii atât în varianta lor negociată, cât și în cazul formării prin adeziune și supuse unor etaloane etice în care specularea avantajelor situaționale face parte din natura comportamentului întreprinderii”. 
natura sau scopul contractului, în special în cazul contractelor de afaceri (comerciale), înseamnă a induce o nesiguranță majoră în circuitul civil, care se va dovedi, în opinia noastră, contraproductivă.

Şi propunerea de modificare a art. 1222 alin. (1) C.civ., prin introducerea posibilității, pentru cel lezat de a solicita nu numai reducerea propriei prestații (forma actuală) ci și „mărirea contraprestaţiei celeilalte părți cu valoarea daunelor-interese la care ar fi îndreptățită să le pretindă” o apreciem discutabilă. Există posibilitatea ca un contractant să dispună doar de o anumită sumă pentru a achiziționa un bun și să fie dispus să încheie contractul doar în limita acelei sume. Chiar și dacă a încheiat un contract disproporționat în favoarea sa, a fi obligat, la solicitarea celui lezat, să plătească, spre exemplu, un preț cu 40\% mai mare, sumă de care nu dispune, ar însemna o încălcare gravă a principiului autonomiei de voință și, uneori, o perturbare gravă a circuitului civil, cum ar fi ipotezele în care bunul, chiar și cumpărat la preț mai mic, a fost achiziționat prin credit bancar. Apreciem că posibilitatea pentru cel lezat de a solicita anularea contractului reprezintă o protecție suficientă. În fine, regretabil este și faptul că nu se renunţă la formularea complet nepotrivită specificului leziunii, privind mărirea sau micşorarea prestației cu „valoarea daunelor-interese la care ar fi îndreptățită să le pretindă”, pentru că induce concluzia greșită că, deși nu se poate cere anularea contractului, s-ar putea cere daune-interese pentru disproporția dintre prestații pe tărâmul răspunderii civile ceea ce, evident, este juridic inacceptabil ${ }^{30}$.

${ }^{30}$ D. CHIRICĂ, op.cit., p. 38-40. 
VII. Câteva considerații finale.

Indiferent de forma de lege care va fi adoptată, măsurile de protecție pentru persoanele cu dizabilități se recomandă a fi flexibile, nu mecanice și uniforme, de natură să permită instanței de tutelă alegerea formei adecvate nu numai în funcție de situația medicală a persoanei protejate, de fluctuațiile eventuale ale efectelor maladiei de care suferă, ci și în funcție de situația patrimonială sau personală a acesteia. Spre exemplu, pentru o persoană care are puține bunuri în patrimoniu, protecția oferită prin familie, eventual prin mecanismul gestiunii paralele, concurente în cazul comunității de bunuri, eventual însoțit de o curatelă se poate dovedi suficientă însă, în cazul unei alte persoane, care deține valori mai mari, s-ar putea să fie nevoie de un mecanism de reprezentare, de genul mandatului de protecție viitoare, sau chiar de instituirea unui regim de ocrotire care să afecteze capacitatea sa de exerciţiu.

Principiile care trebuie să guverneze limitarea capacității persoanei afectate şi măsurile de suport corelative sunt subsidiaritatea, necesitatea și proporționalitatea (și în funcție de situația patrimonială, nu doar de cea medicală și chiar și alte aspecte ale vieții personale).

Dincolo de principiile care ghidează sistemul de protecție al persoanelor cu dizabilități mintale și de influența drepturilor fundamentale ale omului asupra acestor mecanisme, punerea în aplicare a sistemului de reguli de protecție trebuie să răspundă și unor imperative de coerență și predictibilitate. Prea multe forme de limitări ale capacității, uneori lipsite de sisteme de publicitate reale, riscă să creeze confuzie. O posibilă consecință ar fi refuzul de a contracta cu persoanele protejate prin intermediul acestor 
mecanisme, cu consecința, nedorită, ca măsurile de protecție să se întoarcă împotriva intereselor celui protejat.

Ca o concluzie finală, va fi fără îndoială dificil a găsi un echilibru între predictibilitatea limitelor capacității de exercițiu, reclamată de securitatea circuitului civil, și proporționalitatea măsurilor de protecție, care să se moduleze pe situația concretă a persoanei supusă măsurii și care să fie adecvată pentru situația patrimoniului său. Însă tendința este de a prezerva, pe cât este cu putință, autonomia persoanei cu dizabilități, pentru a respecta demnitatea sa. De aceea, este de preferat ca judecătorul de tutelă să poată, într-o anumită măsură, să adapteze regimul incapacității la situația persoanei protejate, nu doar să decidă aplicarea regimului incapacității, sau a unei capacităţi de exercițiu restrânse uniforme. Simpla posibilitate oferită instanței de a modula capacitatea de exercițiu restrânsă, neînsoțită de un sistem de publicitate eficient, apreciem că va rămâne fără utilizare concretă în practică, antrenând riscuri consecutive de neconstituționalitate.

De aceea, apreciem că se impune și introducerea unei măsuri predefinite de suport judiciar pentru persoanele vulnerabile (poate fi și de maniera reformei instituției curatelei, însă terminologic în majoritatea sistemelor legale de referință, curatela presupune o capacitate de exercițiu parțială sau deplină, de regulă cu un sistem de asistență la încheierea actelor) prin care să fie desemnată o persoană care asigură ocrotirea fie prin administrarea patrimoniului sau a anumitor bunuri dacă este cazul, fie prin îndeplinirea sarcinii de asistență la încheierea anumitor categorii de acte. Cel supus măsurii păstrează capacitatea deplină de exercițiu, însă îi pot fi interzise expres încheierea anumitor categorii de acte singur (donații, contracte de întreținere, introducerea de acțiuni în justiție). Pentru a respecta principiul 
Șerban DIACONESCU: Considerații asupra proiectului pentru modificarea și completarea Legii nr. 287/2009 privind Codul civil, a Legii nr.134/2010 privind Codul de procedură civilă, precum și a altor acte normative în materia protecției persoanelor cu dizabilități

necesității impunerii măsurii de reducere/pierdere a capacității de exercițiu, ar trebui să existe și un astfel de mecanism de protecție, cu efecte minimale. 